\title{
Identification and distribution of fishes in fresh water of District Malakand, Khyber Pakhtunkhwa Pakistan
}

\author{
Umar Ali ${ }^{1}$, Qaiser Zaman ${ }^{2}$, Muhammad Farooq ${ }^{1}$ Jawad Ali $^{3^{*}}$ and Rafi \\ $\mathrm{Ullah}^{3}$ \\ 1. Department of Zoology, Government Postgraduate College Dargai, Malakand, Khyber Pakhtunkhwa-Pakistan \\ 2. Department of Zoology, Abdul Wali Khan University Mardan Pakhtunkhwa-Pakistan \\ 3. Department of Agriculture, University of Swabi, Anbar, Swabi-Pakistan \\ *Corresponding author's email: jwd.ali88@gmail.com
}

Citation

Umar Ali, Qaiser Zaman, Muhammad Farooq, Jawad Ali and Rafi Ullah. Identification and distribution of fishes in fresh water of District Malakand, Khyber Pakhtunkhwa Pakistan. Pure and Applied Biology.Vol. 9, Issue 4, pp22972304. http://dx.doi.org/10.19045/bspab.2020.90244

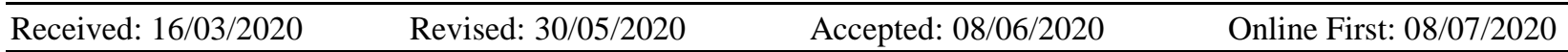

\section{Abstract}

The current study was elaborated the diversity of fresh water fishes in Malakand from 2017 to 2018, the samples were collected at five different locations (Meherdi stream, Kharki stream, Wartier stream, Mahajar camp stream, and Dargai streams), and taxonomically treated as 14 species were identified (Channa punctata, Danio devario, mastacembelus armatus, Barilius pakistanicus, Carassius auratus, Puntius chola, Puntius sarrana, Acanthocobitis botia, Barilius vagra, Ompak pabda, Crossocheilus diplocheilus, Schizothorax plagiostomus, puntius conchinus, Tor putitora) among 14 species, 11 species belong to family of Cyprinidae, One specie is belongs to family ofchannadae, one specie is belongs to mastacembelidae and one specie belong to nemachelidae, it has been observed that Cyprinidae was found most dominant Family in the experimental area and observed from all the localities of Malakand Khyber Pakhtunkhwa, Pakistan.

Keywords: Cyprinidae; Dargaistreams; Danio devario; Fish diversity

\section{Introduction}

Fish is a cold blooded aquatic chordate having gills, fins and body covered with different types of scales [1]. Fishes are more diverse and abundant group of vertebrate and occupied almost every niche of hydrosphere. They showed a great diversity in shape, color and size according to their habitat $[2,3]$. Fishes are a rich source of food, meet, by products such as fish glue, fish oils and fish meals [4]. They are in the diet of many peoples, they provide proteins, fats, and vitamins such as vitamin $\mathrm{A}$, vitamin $\mathrm{B}$, and vitamin $\mathrm{C}$ and also rich source of different type of minerals such as $\mathrm{Ca}, \mathrm{Mg}, \mathrm{P}, \mathrm{Na}, \mathrm{Fe}$, and $\mathrm{I}[5,6]$. Fishes are also an element of most nation economy, they play important role in income of a nation, Stocking of economically viable native fish species in the reservoirs more productive and in as an important measure from aqua biotin point of view $[7,8]$. Some fishes are dangerous by means of poisonous, stinging, biting, and shocking [9]. The identification of fishes fauna are very important feature for studying water body. The diversity of fishes is so much 
numerically; approximately 27,977 (out of 39,900 other vertebrate) species of fishes live in 515 families and 62 orders. Of these, 108 are jawless fish that includes 70 hag fishes and 38 lampreys, 970 cartilaginous sharks, skatess and rays 534 and 33 chimera and remaining 26,000 are bony fishes $[10,11]$. Fishes constitutes slightly more than one half of the total number of living vertebrate species [10]. The freshwater fishes of Pakistan is represented by 193 fish species, These species belong to class Actinopterygii, sub-class Teleostei, 3 cohorts, 6 super orders, 13 orders, 30 families and 86 genera [12, 13]. A vast research work was done on diversity of fresh fishes in Khyber Pakhtunkhwa, Pakistan by several workers. More than 180 species from Indus River, 11 species from Kohat, 94 species from KP and 8 species from Swat are reported from Khyber Pakhtunkhwa, Pakistan [14, 17]. Malakand lies in latitude: 34.616667 and longitude: 71.971389, its total area is $952 \mathrm{~km}^{2}$ and bounded in the east by Swat district, in the north by lower Dir district, in the south east

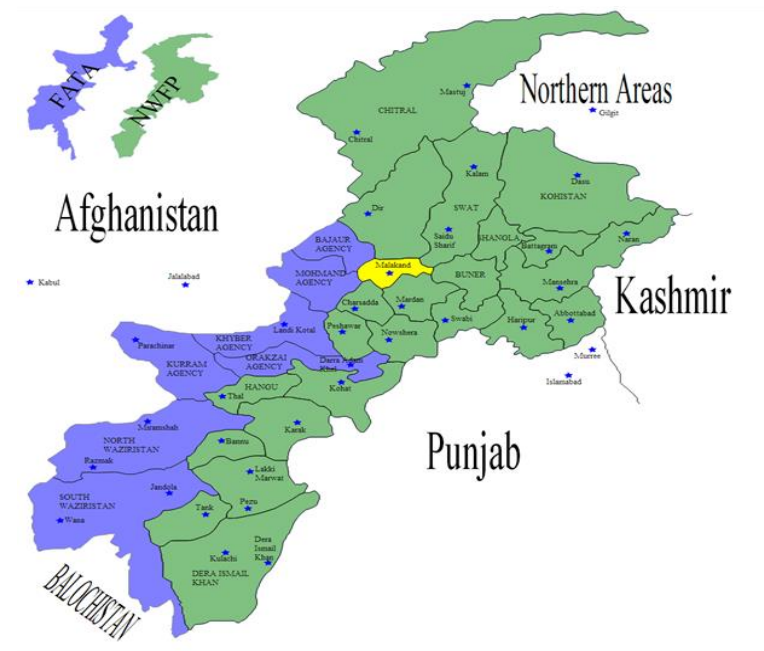

Figure 1. Map of District Malakand

\section{Sampling and preservation}

Random fishes sampling were done on daily basis from Jan 2017 to Dec 2018 in different study sites of District Malakand. The collection was made from different sites of and west by Mardan and Charsadda districts, Malakand is an important position acts as a gateway to Swat, Buner and lower Dir [18, 19]. The main objectives of the present research work are to study the Biodiversity, Distribution, status and to identify the commercially important fishes to avoid the peoples of Malakand from illegal fishing activities.

\section{Materials and methods Collection sites}

The samples were collected in five different areas namely Meherdi, Kharki, warteir, Mahajar camp, and Dargai in the period of Jan 2017 to Dec 2018 in order to explore the fresh water fishes fauna in district Malakand, Khyber Pakhtunkhwa Pakistan. Swat River water passes through a three-mile long tunnel into dargai and wartair streams having high flow of water. Its average depth is about 3-6 feet, while width is 5-15 feet. The Meherdi, Mahajar camp and Kharki streams are small, its depth1-3 and width is about 5-8 feet shown in (Fig. 1).

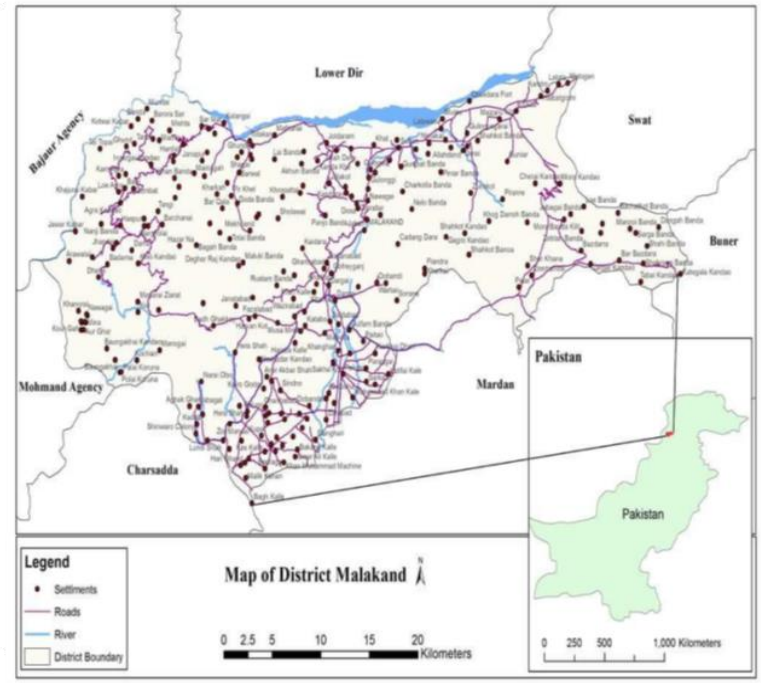

water to avoid specie missing. Immediately after capturing fishes, formalin was injected with in their abdomen to avoid bacterial contaminations. The material was used during the collection includes; automatic 
rods, hand nets, $\mathrm{PH}$ meter, thermo meter, mobile GPS, measuring tape and digital camera. Fishes was dropped into a solution of dilute formalin (3\%). The solution was made by diluting one part of commercial formalin (37\%) with 20 parts of water. Then fishes were dropped to those solutions in bottles and those bottles were brought to laboratory of Animals Sciences Government post graduate college Dargai, Malakand with attached labels.

\section{Identifications}

Various morphometric measurements of fishes were taken by ruler. Other instruments used for laboratory work are petri dishes, surgical gloves, tissue papers, magnifying glasses and classification was done through various taxonomic and systematic keys [20, 21]. According to these keys and system each fish is identified on the basis of size, shape, color, fin structure and different marks on the fish body.

\section{Results and discussion}

A total of 480 specimens of 14 species shown in (Table 1) and in (Fig. 2) and their Percentage contribution to their families shown in (Fig. 3) belong to 4 families and 10 genera were collected from District Malakand Khyber Pakhtunkhwa Pakistan. About 11 (78.57\%) of individuals to eleven species belonged to family cyprinidae followed by $1(7.1 \%)$ of individual of Channa punctata belonged to channidae 1 (7.1\%) of individual metacemballus armatus belonged to metacembilidae and $1(7.1 \%)$ of individual acanthobitis botia belonged to nemachelidae. The present collection clearly shows that the family cyprinidae is the most dominant family in District Malakand KP, Pakistan. In district Malakand streams have both small and large size fishes. The Danio devario, Barilius pakistanicus, Puntiuschola, Acanthocobitis botia, Barilius vagra, Ompak pabda, Crossocheilus diplocheilus, Puntius conchonius, are the smaller size fishes of
District Malakand. These smaller size fishes have no marketing valves because of their size, but due to the part of biodiversity they play a very important role in aquatic ecosystem. The Danio devario, Barilius pakistanicus are the beautiful important ornamental fishes are used to keep alive in aquarium that allow great economic valve. Beside the mastacembelus Armatus, Carassius auratus, Puntius sarrana, Schizothorax plagiostomus, Tor putitora, Channa punctata, are the large size and valuable fishes of District Malakand. The detail of abundance and absence with local names are shown in (Table 1), while the Morphometric measurment of fish species in District Malakand are shown in (Table 2).

The current research project biodiversity of fresh water fishes in district Malakand conducted from Jan 2017 to Dec 2018. In the present fish biodiversity study 14 species, 10 genera and 4 families of fresh water fishes recorded for the first time from District Malakand streams. The most abundant dominant family was to be found is cyprinidae which includes 11 species namely;Channa punctata, Danio devario, mastacembelus armatus, Barilius pakistanicus, Carassius auratus, Puntius chola, Puntius sarrana, Acanthocobitis botia, Barilius vagra, Ompak pabda, Crossocheilus diplocheilus, Schizothorax plagiostomus, puntius conchinus and Tor putitora. The family mastacembelidae include one specie Mastacembelus armatus and the family nemanchelidae include Acanthocobitis botia and the family channidaeinclude Channa punctata. Zebra fish (Danio devario) were collect from Meherdi stream. The zebra fish was the most abundant in Meherdi stream, because of Meherdi stream is good habitat for the zebra fish because biochemical aspects of Meherdi stream water are perfect for zebra fish survival. 
Ali et al.

. Table 1. Species abundance and absence with local names

\begin{tabular}{|c|c|c|c|c|c|c|c|}
\hline Species name & $\begin{array}{l}\text { Local } \\
\text { name }\end{array}$ & family & $\begin{array}{l}\text { Dargai } \\
\text { stream }\end{array}$ & $\begin{array}{c}\text { Mahajar } \\
\text { camp } \\
\text { stream } \\
\end{array}$ & $\begin{array}{l}\text { Wartair } \\
\text { stream }\end{array}$ & $\begin{array}{c}\text { Khark } \\
\text { i } \\
\text { stream }\end{array}$ & $\begin{array}{l}\text { Meherdi } \\
\text { stream }\end{array}$ \\
\hline Tor putitora & Bragi & Cyprinidae & + & - & ++ & - & ++ \\
\hline Danio devario & Sindani & Cyprinidae & - & - & - & + & ++ \\
\hline $\begin{array}{l}\text { Schizothorax } \\
\text { plagiostomus }\end{array}$ & Kharrai & Cyprinidae & ++ & - & ++ & - & - \\
\hline $\begin{array}{c}\text { Barilius } \\
\text { pakistanicus, }\end{array}$ & Sital & Cyprinidae & - & - & - & + & + \\
\hline Barilius vagra & Sital & Cyprinidae & - & - & - & + & + \\
\hline Puntiuschola & Khatapa & Cyprinidae & + & - & ++ & - & ++ \\
\hline Puntius sarrana & Khatapa & Cyprinidae & + & - & ++ & - & + \\
\hline Puntiusconchonius & Khatapa & Cyprinidae & + & - & ++ & - & + \\
\hline Ompak pabda & Singlai & Cyprinidae & - & - & - & + & ++ \\
\hline $\begin{array}{l}\text { Crossocheilus } \\
\text { diplocheilus }\end{array}$ & $\begin{array}{l}\text { Sodai } / \mathrm{k} \\
\text { arra }\end{array}$ & Cyprinidae & ++ & + & ++ & - & + \\
\hline Carassius auratus & Paplate & Cyprinidae & + & - & ++ & - & ++ \\
\hline $\begin{array}{l}\text { Mastacembelus } \\
\text { armatus }\end{array}$ & $\begin{array}{l}\text { Marma } \\
\text { hay }\end{array}$ & $\begin{array}{l}\text { mastacembe } \\
\text { lidae }\end{array}$ & + & ++ & + & + & ++ \\
\hline Acanthocobitis botia & Kata & $\begin{array}{c}\text { nemachelida } \\
\text { e }\end{array}$ & + & + & ++ & + & ++ \\
\hline Channa punctata & Kata & channadae & - & - & + & - & ++ \\
\hline
\end{tabular}

Keys: ++ most abundance, +abundance, -absence

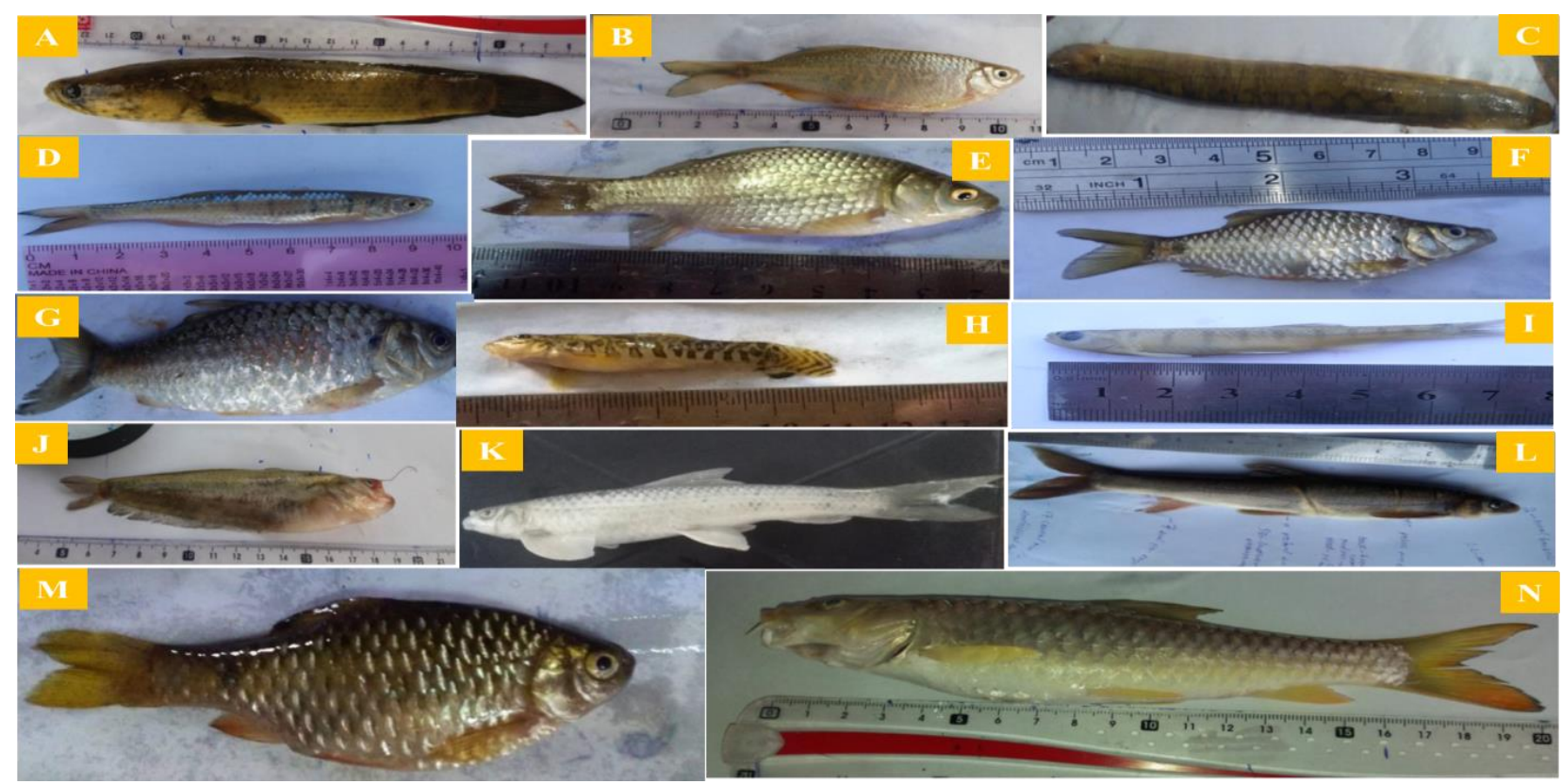

Figure 2. $\mathrm{A}=$ Channa punctata, $\mathrm{B}=$ Danio devario, $\mathrm{C}=$ Mastacembelus armatus, $\mathrm{D}=$ Barilius pakistanicus, E=Carassius auratus, $\mathrm{F}=$ Puntius chola, $\mathbf{G}=$ Puntius sarrana, $\mathrm{H}=$ Acanthocobitis botia, $\mathrm{I}=$ Barilius vagra, $\mathrm{J}=$ Ompak pabda, $\mathrm{K}=$ Crossocheilus diplocheilus, $\mathrm{L}=$ Schizothorax plagiostomus, $\mathrm{M=Puntius} \mathrm{conchonius,} \mathrm{N}=$ Tor putitora 


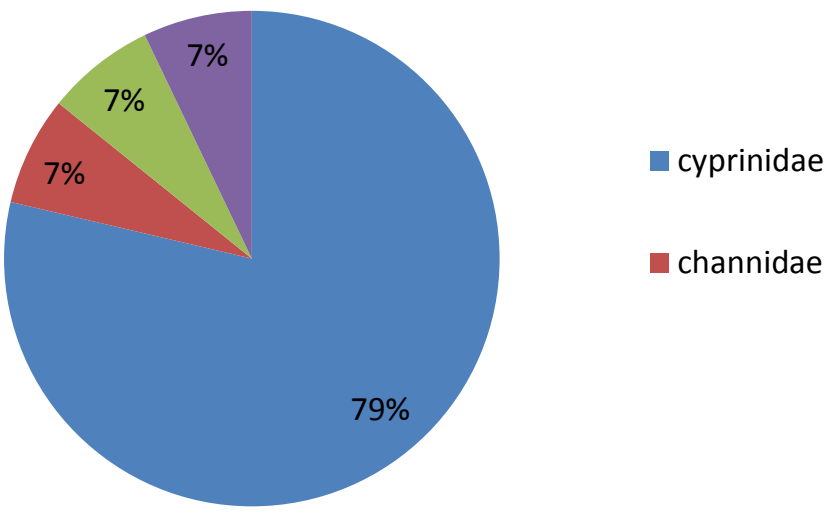

Figure 3. Percentage contribution of recorded fish species to their families

Table 2. Morphometric measurment of fish species in District Malakand

\begin{tabular}{|c|c|c|c|c|c|c|}
\hline Fish name & T.L/cm & S.T/cm & H.L/cm & E.Di/cm & B.D/cm & T.H/cm \\
\hline Tor putitora & 14.5 & 12 & 3 & 0.5 & 3 & 2.8 \\
\hline Danio devario & 13 & 10.3 & 2 & 0.8 & 4 & 2.4 \\
\hline $\begin{array}{l}\text { Schizothorax } \\
\text { plagiostomus }\end{array}$ & 17 & 14.3 & 2.8 & 0.5 & 3 & 3.9 \\
\hline $\begin{array}{c}\text { Barilius } \\
\text { pakistanicus, }\end{array}$ & 11.3 & 9.5 & 1.8 & 0.5 & 2 & 2 \\
\hline Barilius vagra & 16.3 & 14 & 2 & 1.6 & 3 & 3.1 \\
\hline Puntius chola & 13.5 & 10.2 & 2.8 & 0.8 & 4.4 & 3.2 \\
\hline $\begin{array}{l}\text { Puntius } \\
\text { sarrana }\end{array}$ & 15 & 12.5 & 3 & 0.4 & 5 & 4.8 \\
\hline $\begin{array}{c}\text { Puntius } \\
\text { conchonius }\end{array}$ & 12 & 9.5 & 2 & 0.7 & 4.2 & 2.5 \\
\hline Ompak pabda & 10.9 & 10.2 & 2.6 & 0.4 & 2.5 & 1.4 \\
\hline $\begin{array}{c}\text { Crossocheilus } \\
\text { diplocheilus }\end{array}$ & 16 & 15 & 1.8 & 0.5 & 3 & 2.5 \\
\hline $\begin{array}{c}\text { Carassius } \\
\text { auratus }\end{array}$ & 11.5 & 9 & 2.3 & 0.9 & 4 & 3.5 \\
\hline $\begin{array}{c}\text { Mastacembelus } \\
\text { armatus }\end{array}$ & 18.2 & 9.7 & 2 & 0.8 & 2.5 & 1 \\
\hline $\begin{array}{c}\text { Acanthocobitis } \\
\text { botia }\end{array}$ & 8.2 & 7 & 1 & 0.6 & 2 & 1.7 \\
\hline $\begin{array}{l}\text { Channa } \\
\text { punctata }\end{array}$ & 31 & 29 & 5 & 0.9 & 3 & 2 \\
\hline
\end{tabular}

Key; T.L total length, S.T standard length, H.L head length, E.Di eye diameter, B.D body depth, T.H tail highet.

The zebra fish have simple breeding and this stream is good for their breeding. The zebra fishes might be decline in future because some bizarre ways people use for killing fishes most dangerously electric currents.
Beside the plagiostomus, Schizothorax, Crossocheilus diplocheilus, Tor putitora have a high numbers in Dargai and wartair streams. The rarest species in the present collection were Barilius pakistanicus, 
Barilius vagra. According to Akhtar [22] reported 10 species belongs to 3 orders and 4 families it includes, Barilius pakistanicus, Triplophysa naziri, Tor putitora, Crossocheilus latius, Schizothorax plagiostomus, Channa gachua, Garagotyla, Mastacembelus armatus, Puntius sophore, and Schistura punjabensis. The data they collected from river Barandu District Buner Khyber Pakhtunkhwa. Saeed [23] reported 11 species which belongs to 3 orders and 4 families from river brandu. Ishaq [24] reported 18 species which belongs to 5 orders and 6 families from chakdara river sawat, the dominant family were cyprinidae follewod by 10 species. Hasseb [25] reported seven species from from Nayab dam district Hangu, Hameed reported 5 species from ghurzandi dam District Kohat. During this study the factors like $\mathrm{PH}$, Temperatures etc are recoded, these factors are responsible for the variety of fish species found in area. The richness of the fish species is in area is due to these factors. During the present study Schizothorax plagiostumous specie were recorded in Dargai and wartair streams, their water $\mathrm{PH}$ was 6.5 to $7.5^{\circ} \mathrm{C}$ and temperatures 14 to $22^{\circ} \mathrm{C}$. Yousafzai [26] recorded the temperature of river swat ranged from 15-26 ${ }^{\circ} \mathrm{C}$. Dargai and wartair streams are arise from Swat River at Batkhela, since it is migrated specie from river Swat. The present collected species contains both large and small size fishes. The Danio devario, Barilius pakistanicus, Puntius chola, Acanthocobitis botia, Barilius vagra, Ompak pabda, Crossocheilus diplocheilus, Puntius conchonius are smaller size fishes of district Malakand, due to their size these fishes have no marketing valve but they play a very important role in riverine ecosystem. Zebra fish (Danio deverio) have a great diversity (have abundant) in Meherdi stream, the zebra fish is so important to scientific research i.e. it is valuable model for studying human genetics, to study the function of genes, to develop new human drugs because of each couple of produce up to 200 embryo in every seven days, these embryo and larvae are small and transparent undergo rapid external developments [27]. The Schizothorax plagiostumus (Swati/ kharri fish) and Tor pititura (mahasheer) are the important commercial fishes in District Malakand, Khyber Pakhtunkhwa, Pakistan.

\section{Conclusion and recommendations}

The present study was conducted for the first time from Jan 2017 to Dec 2018 to explore the diversity of fresh water fishes in District Malakand KP, Pakistan. During the present surveys 14 species were collected, identified, persevered, and labeled in the Department of animals' sciences GPGC, Dargai Malakand. The most dominant family was recorded as cyprinidae, followed by 11 species out of 14 . It could be rightly concluded that the present collected species has some of the important commercial fishes like Swati fish, mahasheer and zebra fishes, found in Meherdi, Dargai and Wartair streams. The anthropogenic activities like oil spills, over hunting, the aquatic pollution from the ghee mills and steels mills are highly affected the diversity and may stop the growth of these commercially important fishes. To conserve this important ichthyofauna in the District Malakand, the authorities need to play a critical role especially in managing and to aware the people of District to control illegal fishing technique like electric currents, dynamites.

\section{Authors' contributions}

Conceived and designed the experiments: U Ali \& Q Zaman, Performed the experiments: U Ali, Analyzed the data: M Farooq, Contributed materials/ analysis/ tools: J Ali \& Rafiullah, Wrote the paper: U Ali.

\section{Acknowledgment}

The authors are grateful to the Department of Zoology GPGC Dargai, Malakand, Khyber Pakhtunkhwa, Pakistan for providing lab facilities. The author would like to thanks Mr. 
Qaiser Zaman, Lecturer in the GPGC, Dargai Malakand for giving useful suggestions and cooperation in this research. The authors have no conflict of interest.

\section{References}

1. Din A, Saeed K, Akhtar N, Khan A, Rafique N \& Khan J (2016). Exploring the Fish Fauna of River Chamla District Buner KPK, Pakistan. Acad J of Sci Res 215-216.

2. Qadđr A, Malđk RN, Ahmad T \& Sabđr AM (2009). Patterns and distribution of fish assemblage in Nullah Aik and Nullah Palkhu Sialkot, Pakistan 2(2): 110-124.

3. Akin S, Buhan E, Winemiller $\mathrm{KO}$ \& Yilmaz H (2005). Fish assemblage structure of Koycegiz Lagoon-Estuary, Turkey: Spatial and temporal distribution patterns in relation to environmental variation. Estuarine, Coastal and Shelf Sci 64(4): 671-684.

4. Khan MA, \& Hasan Z (2011). A preliminary survey of Fish fauna of Changhoz Dam, Karak, KPK, Pakistan. World J of Fish and Marine Sci 3(5): 376-378.

5. Krogdahl $\AA$, Hemre GI \& Mommsen TP (2005). Carbohydrates in fish nutrition: digestion and absorption in postlarval stages. Aquacul Nutr 11(2): 103-122.

6. Shaikh HM, Kamble SM \& Renge AB (2011). The study of ichthyofauna diversity in upper Dudhna project water reservoir near Somthana in Jalna district (MS) India. $J$ of Fisheries and Aquacul 2(1): 8.

7. Sinha MP (1986). Limnobiotic study on trophic status of a polluted freshwater reservoir of coal field area. Poll Res 15: 13-17.

8. Shinde SE, Pathan TS, Bhandare R Y, \&Sonawane D L (2009). Ichthyofaunal Diversity of Harsool Savangi Dam, District Aurangabad (MS) India. World $J$ of Fish and Marine Sci 1(3): 141-143.
9. Rafique M \& Khan NUH (2012) Distribution and status of significant freshwater fishes of Pakistan. Rec Zool Surv Pak 21: 90-95.

10. Dubey AK, Shukla SK, \& Verma H (2012). Ichthyo-Diversity of Banisagar Dam at Chhatarpur, Madhya Pradesh, India. Inter $J$ of Fisheries and Aquatic Sci 2: 157-161.

11. Saeed K, Khan S \& Haq F (2013). Diversity and population status of fish fauna of river Barandu district Buner Khyber Pakhtunkhwa Province Pakistan. $J$ of Biodiv and Environ Sci 5(2): 83.

12. Kar D, Nagarathna AV, Ramachandra TV \& Dey SC (2006). Fish diversity and conservation aspects in an aquatic ecosystem in Northeastern India. Zoos' Print J 21(7): 2308-2315.

13. Rafique M \& Khan NUH (2012). Distribution and status of significant freshwater fishes of Pakistan. Rec Zool Surv Pak 21: 90-95.

14. Mirza MR \& Mirza ZS (2014). Longitudinal Zonation in the Fish Fauna of the Indus River in Pakistan. Biologia 60(1): 149-152.

15. Haseeb A, Azeem T, Masood Z, Mengal F, Rehman UH \& Fayyaz A (2015). An Investigation on Freshwater Fish Fauna of Tanda Dam in Kohat District, KPK, Pakistan. Global Vet 4: 576.

16. Butt JA (1986). Fish and Fisheries of KPK Pakistan. Biologia (Pak) Special Supplement 21-34.

17. Ahmad ND \& Mirza MR (1963). Loaches of genus Noemacheilus Hasselt from Swat State, West Pakistan. PJS 15: 75-81.

18. Khan MA, Yousafzai AM, Afshan N, ul Akbar N, Raza MK, Hussain H, \& Mumtaz T (2015). Physicochemical Parameters of water Collected from River Panjkora, KPK, Pakistan. World J of Fish and Marine Sci 7(6): 462-471. 
19. Hazrat A, Shah J \& Nisar M (2011). Medicinal plants of Sheringal Valley, Dir Upper, KPK, Pakistan. FUUAST J of Biol 1(2): 131-133.

20. Muhammad H, Iqbal Z \& Saleemi S (2018). Diversity and distribution of fish fauna of Indus River at Taunsa Barrage in Punjab, Pakistan. Pak J Zool 49(1): 155-161.

21. Rehman HJU, Khabir MN, KhanAS, Hassan Z, Khan I \& Khan MK (2020). 49. Morphometric measurement, relative abundance and effect of physicochemical parameters of water on ichthyofaunistic diversity of River Tochi District North Waziristan (Newly Merged District), KPK. Pure and Appl Biol 9(1): 501-506.

22. Akhtar N, Khan S \& Saeed K (2014). Exploring the Fish Fauna of River Swat, KPK, Pakistan. World J of Fish and Marine Sci 6(2): 190-194.

23. Saeed K, Khan S \& Haq F (2013). Diversity and population status of fish fauna of river Barandu district Buner
Khyber Pakhtunkhwa Province Pakistan. J of Biodiv and Environ Sci (4): 83.

24. Ishaq M, Khan S, Khan J, Akhtar N \& Saeed K (2014). Fish biodiversity of River Swat from Madyan to Chakdara. World J of Fish and Marine Sci 5(4): 1076-1080.

25. Haseeb A, Yaseen HUR, Zareen S, Haleem S, Khan HA, Khan A \& Rafiq N (2016). Ichthyo-diversity of Naryab dam district Hangu KPK Pakistan. $J$ of Entomol and Zool Stud 4(5): 608-610.

26. Yousafzai AM, Khan W \& Hasan Z (2013). Fresh records on water quality and ichthyodiversity of River Swat at Charsadda, KPK. Pak J of Zool 6: 45.

27. Darwall WRT \& Vié JC (2005). Identifying important sites for conservation of freshwater biodiversity: extending the species-based approach. Fisheries Manag and Ecol 12(5): 287-293. 